\title{
PENGGUNAAN TEPUNG CACING TANAH (Lumbricus rubellus) SEBAGAI ADITIF PAKAN TERHADAP PENAMPILAN PRODUKSI AYAM PEDAGING, PROFIL DARAH, DAN KECERNAAN PROTEIN
}

\section{THE EFFECT OF EARTHWORM (Lumbricus rubellus) MEAL AS FEED ADDITIVE ON BROILER PRODUCTION PERFORMANCE, BLOOD PROFILE, AND PROTEIN DIGESTIBILITY}

\author{
Hardi Julendra ${ }^{1}$, Zuprizal $^{2}$, dan Supadmo ${ }^{2}$ \\ ${ }^{1}$ Unit Pelaksana Teknis Balai Pengembangan Proses dan Teknologi Kimia, Lembaga Ilmu Pengetahuan Indonesia \\ (LIPI), Dusun Gading, Playen, Gunungkidul, Daerah Istimewa Yogyakarta \\ ${ }^{2}$ Fakultas Peternakan, Universitas Gadjah Mada, Jl. Fauna No.3, Bulaksumur, Yogyakarta, 55281
}

\section{INTISARI}

Penelitian ini bertujuan untuk mempelajari penggunaan tepung cacing tanah (TCT) (Lumbricus rubellus) sebagai aditif pakan terhadap penampilan produksi ayam pedaging, profil darah, dan kecernaan protein. Penelitian ini menggunakan 100 ekor doc strain cobb (CP 707) yang dipelihara selama 35 hari. Ternak dibagi secara random menjadi empat perlakuan (R0: tanpa aditif TCT, R1: aditif TCT 0,5\%, R2: aditif TCT 1\%, R3: aditif TCT 1,5\%) dengan lima ulangan, setiap ulangan diisi lima ekor ayam. Penelitian menggunakan Rancangan Acak Lengkap (RAL) pola searah dengan uji lanjut Duncan. Uji performa dilakukan dengan mencatat pertambahan berat badan, konsumsi pakan, dan efisiensi ransum. Uji profil darah dilakukan dengan menghitung jumlah sel eritrosit, leukosit sedangkan uji kecernaan protein menggunakan metoda koleksi ekskreta dan koleksi isi illeum. Hasil penelitian menunjukkan bahwa konsumsi pakan R1 (2.065 g), R2 (2.025,4 g), R3 (2.075,3 g) berbeda nyata $(\mathrm{P}<0,05)$ dengan R0 (2.309,8 g) sedangkan pertambahan berat badan berbeda tidak nyata dan FCR pada R1 $(1,78)$, R2 $(1,78)$, R3 $(1,78)$ berbeda nyata $(\mathrm{P}<0,05)$ dengan R0 (2,04). Hasil pengujian profil darah memperlihatkan bahwa jumlah sel eritrosit berbeda tidak nyata, jumlah sel leukosit R1 $(18.575 \mu \mathrm{l}), \mathrm{R} 2(18.200 \mu \mathrm{l})$, R3 $(20.175 \mu \mathrm{l})$ berbeda nyata $(\mathrm{P}<0,05)$ dengan R0 $(16.675 \mu \mathrm{l})$ dan limfosit R1 (22,7\%),R2 (21,8\%), R3 (23,6\%) berbeda nyata $(\mathrm{P}<0,05)$ dengan R0 (15,2\%). Kecernaan protein R3 $(91,69 \%)$ berbeda nyata $(\mathrm{P}<0,05)$ dengan R0 (81,75\%), R1 (90,48\%) dan R2 (85,99\%). R1 (90,48\%) berbeda nyata $(\mathrm{P}<0,05)$ dengan R0 (81,75\%) tetapi R2 (85,99\%) berbeda tidak nyata dengan R0 (81,75\%). Penggunaan tepung cacing tanah sebagai aditif ternyata dapat memperbaiki penampilan produksi ayam pedaging, memperbaiki kesehatan ternak dilihat dari profil darah, dan mampu meningkatkan kecernaan protein.

(Kata kunci: Pakan aditif, Tepung cacing tanah, Ayam pedaging)

\section{ABSTRACT}

The objective of this research was to study the use of earthworm meal (Lumbricus rubellus) (TCT) as feed additive on broiler performance, blood profile and protein digestibility. The experiment used 100 day old chicken of cobb strain (CP 707), for 35 days feeding trial. The birds were randomly divided into four dietary treatments (R0: without TCT addition, R1: 0.5\% TCT addition, R2: 1\% TCT addition, R3: 1.5\% TCT addition) with five replications, wich consisted five chickens each. The experimental design used Completely Randomized Design (CRD) of one way ANOVA then continued with Duncan test. Performance test was conducted by recording body weight gain, feed consumption and feed efficiency. Blood profile test was obtained by counting the number of erythrocyte, leukocyte and lymphocytes, whereas protein digestibility test used the collection method of excreta and ileum content. The result showed that feed consumption of $R 1(2,065 \mathrm{~g}), R 2(2,025.4 \mathrm{~g}), R 3(2,075.3 \mathrm{~g})$ were significantly different $(P<0.05)$ from $R 0$ (2,309.8 g), while the body weight gain were not different among treatments and FCR of R1 (1.78), R2 (1.78), R3 (1.78) were significantly different $(P<0.05)$ from $R 0$ (2.04). The result of blood profile test showed that the number of erythrocyte among treatments were not significantly different, the number of leukocyte of R1 (18,575 $\mu$ l), R2 (18,200 $\mu l), R 3(20,175 \mu l)$ were found significantly higher $(P<0.05)$ than $R 0(16,675 \mu l)$ and lymphocytes of $R 1(22.7 \%), R 2$ (21.8\%), R3 (23.6\%) were significantly higher $(P<0.05)$ than R0 (15.2\%). Protein digestibility of R3 (91.69\%) was significantly different $(P<0.05)$ from $R 0$ (81.75\%), R1 (90.48\%) and R2 (85.99\%), while R1 (90.48\%) was significantly different $(P<0.05)$ from $R 0$ (81.75\%), but R2 (85.99\%) was not significantly different from R0 (81.75\%). It could be inferred that earthworm meal addition as feed additive could improved production performance of broiler, the poultry health through blood profile, and enhanced the protein digestibility.

(Key words: Feed additive, Earthworm meal, Broiler)

\footnotetext{
* Korespondensi (corresponding author):

Telp.+62 8180274 6669, E-mail: hard003@lipi.go.id
} 


\section{Pendahuluan}

Pakan yang berkualitas umumnya menggunakan tambahan bahan-bahan aditif (Patrick dan Schaible, 1980) seperti enzim, vitamin, antibiotik, dan lain sebagainya (Wahyu, 2004). Aditif untuk memacu pertumbuhan pada ayam pedaging salah satunya adalah antibiotik (antibiotics growth promoters) karena antibiotik selain dapat meningkatkan immunogenik (Boogard dan Stobberigh, 1999) juga dapat meningkatkan efisiensi penggunaan pakan (Wahyu, 2004) dan meningkatkan berat badan ayam broiler sampai 100 gram pada umur 6 minggu (Sundu, 2007).

Ada beberapa teori yang menjelaskan mekanisme kerja dari antibiotics growth promoters (AGP's) yaitu: antibiotik membantu menjaga nutrisi dari destruksi bakteri, membantu meningkatkan absorbsi nutrien karena membuat barier di dinding usus, menurunkan produksi toksin dari bakteri saluran pencernaan dan menurunkan kejadian infeksi saluran pencernaan subklinik (Feihgner dan Dashkevics, 1987). Antibiotik dapat meningkatkan performa vili usus (Rofiq, 2003), sehingga absorbsi makanan dalam usus meningkat (Wahyu, 2004). Dari tinjauan tersebut ternyata AGP's dapat memaksimalkan absorbsi nutrien dalam saluran cerna, sehingga memacu pertumbuhan dan mengefisiensikan konsumsi pakan.

Masalahnya adalah bahwa AGP's yang dipakai saat ini adalah produk semi sintetis (Hakim, 2005), dalam pakan ternak seringkali tidak murni berasal dari mikroba, tetapi berupa antimikroba yang disintesis secara kimiawi (Cook et al., 1997) sehingga penggunaannya dalam waktu yang lama akan menimbulkan efek resistensi pada bakteri patogen sasaran. Residu antibiotik menimbulkan dampak kesehatan bagi manusia yang mengkonsumsinya (Donoghue, 2003). Penggunaan streptomycin, sulfadiazine, dan tetracycline pada suplemen pakan terbukti menyebabkan resisten terhadap Escherichia coli (Khachatryan et al., 2006), sehingga World Health Organisation (WHO) menyarankan semua negara melakukan surveilens terhadap resistensi antibiotika baik pada manusia maupun hewan (Castanon, 2007). Regulasi WHO tersebut membuat industri obat-obatan mulai mengembangkan bahan alami pengganti antibiotik. Salah satunya adalah tepung cacing tanah (TCT) karena mengandung zat anti bakteri seperti cacing tanah Eisinia foetida (Lange et al., 1999), Theromyzon tessulatum (Tasiemski et al., 2006), dan Lumbricus rubellus (Cho et al., 1998). Penambahan $1 \%$ protecting agent dalam TCT mampu memperbaiki retensi nitrogen (Sofyan et al., 2008) dan menghambat perkembangan bakteri Salmonella pullorum dan E-colli (Julendra dan Sofyan 2007).
TCT diketahui memberi efek terhadap peningkatan imunitas ternak (Damayanti et al., 2009) dan dapat menstimulasi sistem kekebalan (Liu et al., 2004).

Penelitian ini mencoba mempelajari penggunaan tepung cacing tanah dalam bentuk aditif terhadap performa, profil darah (eritrosit, leukosit dan limfosit) dan kecernaan protein. Sehingga dapat menjawab apakah penggunaan tepung cacing tanah (Lumbricus rubellus) sebagai aditif mampu meningkatkan penampilan produksi, profil darah dan kecernaan protein.

\section{Materi dan Metode}

\section{Lokasi dan Waktu Penelitian}

Penelitian berlangsung dari bulan September sampai November 2009, dimulai dengan uji biologis yang dilaksanakan di kandang unggas Laboratorium Biokimia Fakultas Peternakan UGM Yogyakarta selama 40 hari dan dilanjutkan dengan uji laboratorium.

\section{Materi}

Materi yang digunakan adalah ayam broiler sebanyak 100 ekor DOC strain Cobb (CP 707), pakan formulasi, filler dan tepung cacing tanah terformulasi (TCT) dengan komposisi kimia protein 63,08\%, lemak 18,51\%, dan lumbricin 0,1\%. Pakan dibuat sesuai dengan persyaratan SNI untuk ayam pedaging. Kandang yang digunakan adalah kandang cage (kotak) berukuran $1 \times 1 \times 0,6 \mathrm{~m}^{3}$ beralas ram kawat berlobang dilengkapi dengan lampu indukan 60 watt, masing-masing kandang dilengkapi dengan tempat makan dan minum dan unit penampung ekskreta.

\section{Metode}

Feeding trial (uji biologis). Ayam dipelihara dari DOC sampai umur 35 hari dalam kandang cage dilengkapi tempat makan dan minum. Pakan diberikan pagi dan sore, dan air minum diberikan secara ad libitum. Konsumsi pakan dicatat setiap hari dan pertambahan berat badan diukur setiap minggu. Selama penelitian ayam divaksin Newcastle Disease (ND) untuk menghindari penyakit Newcastle Disease pada umur 1 hari dan umur 18 hari. Ransum dibuat dan disesuaikan dengan SNI No 013931-1995 seperti pada Tabel 1.

Rancangan Penelitian. Penelitian dilakukan dengan membandingkan pengaruh level penambahan tepung cacing tanah (TCT) 0,$5 ; 1,0$; dan 1,5\%, dan untuk menselaraskan penggunaan pakan ditambahkan filler. Terdapat empat perlakuan dengan lima ulangan dan setiap ulangan terdiri dari lima ekor ayam. Pakan perlakuan terdiri dari R0 (filler $1,5 \%+0 \%$ TCT), R1 (filler 1,0\%+0,5\% TCT), R2 (filler $0,5 \%+1,0 \%$ TCT), dan R3 (filler $0 \%+1,5 \%$ 
Tabel 1. Ransum penelitian (dietary ration composition)

\begin{tabular}{lrrrr}
\hline \multicolumn{1}{c}{ Bahan (feedstuffs) } & R0 & R1 & \multicolumn{1}{c}{ R2 } & \multicolumn{1}{c}{ R3 } \\
\hline Jagung (\%) (corn meal (\%)) & 63,00 & 63,00 & 63,00 & 63,00 \\
Dedak halus (\%) (rice bran (\%)) & 7,00 & 7,00 & 7,00 & 7,00 \\
Bungkil kedelai (\%) (soybean meal (\%)) & 15,00 & 15,00 & 15,00 & 15,00 \\
Poultry meat meal (\%) & 12,50 & 12,50 & 12,50 & 12,50 \\
Decalsiumphosphat (\%) & 0,50 & 0,50 & 0,50 & 0,50 \\
Minyak kelapa (\%) (coconut oil (\%)) & 0,50 & 0,50 & 0,50 & 0,50 \\
Filler (\%) & 1,50 & 1,00 & 0,50 & 0,00 \\
TCT (\%) & 0,00 & 0,50 & 1,00 & 1,50 \\
\hline Jumlah (\%) & 100,00 & 100,00 & 100,00 & 100,00 \\
\hline Komposisi kimia ransum perlakuan (chemical composition & & & & \\
of experimental diets) & & & & \\
ME (kcal/kg) & 3.200 & 3.200 & 3.200 & 3.200 \\
CP (\%) & 19,80 & 20,20 & 20,50 & 20,80 \\
Lemak (\%) (fat (\%)) & 4,50 & 4,50 & 4,60 & 4,70 \\
Serat kasar (\%) (crude fibre (\%)) & 3,80 & 3,80 & 3,80 & 3,80 \\
Ca (\%) & 1,00 & 1,00 & 1,00 & 1,00 \\
P (\%) & 0,70 & 0,70 & 0,70 & 0,70 \\
lumbricin $(\mu \mathrm{g} / \mathrm{g})$ & 0 & 0,0005 & 0,001 & 0,0015 \\
\hline
\end{tabular}

TCT: tepung cacing tanah (earthworm meal), ME: metabolisable energy, CP: crude protein. R0: TCT 0\%, R1: TCT 0,5\%, R2: TCT 1,0\%, R3: TCT 1,5\%.

TCT). Data penampilan produksi, profil darah, dan kecernaan dianalisis variansi menggunakan Rancangan Acak Lengkap (RAL) pola searah. Apabila terdapat perbedaan nyata antar perlakuan, analisis dilanjutkan dengan uji Duncan Multiple Range Test (DMRT) menurut Steel dan Torrie (1993).

\section{Variabel performan ayam broiler}

Total konsumsi. Total konsumsi dihitung dengan rumus :

Total konsumsi (g/ekor) = jumlah konsumsi dari hari ke-1 sampai hari ke-32.

Pertambahan bobot badan (PBB). Pertambahan bobot badan diukur dari selisih penimbang bobot badan akhir minggu dengan awal minggu dalam gram/ekor. Total pertambahan bobot badan dihitung menggunakan rumus :

PBB (g/ekor) = (jumlah PBB minggu II sampai V)

Konversi pakan atau feed conversion ratio (FCR). FCR dihitung dengan rumus :

$$
\text { FCR }=\frac{\text { Total konsumsi pakan }}{\text { Total PBB }}
$$

Pemeriksaan darah. Pengambilan sampel darah pada umur ayam 32 hari yang diambil dari dua ekor ayam yang dipilih secara acak disetiap kandang. Sampel darah diambil menggunakan spuit $3 \mathrm{ml}$, jarum ditusukkan kedalam pembuluh vena pada bagian humerus. Darah dihisap secara perlahan sebanyak 2,5 ml dan dimasukkan ke microtube yang sudah diberi antikoagulan EDTA (Ethylene Diamine Tetra Acetic). Pemeriksaan darah meliputi perhitungan jumlah eritrosit, leukosit, dan limfosit dilakukan di Bagian Patologi Klinik, Fakultas Kedokteran Hewan, Universitas Gadjah Mada.

Koleksi ekskreta dan digesta. Koleksi ekskreta dan digesta bertujuan untuk uji kecernaan protein yang dilaksanakan pada saat umur ayam 33 sampai 35 hari menggunakan 18 ekor ayam terdiri dari 4 perlakuan (R0, R1, R2, dan R3) dengan tiga ulangan ditambah enam ekor ayam yang dipuasakan (kecernaan metabolik), berdasarkan teknik koleksi ekskreta Lee et al. (2004) dan Mulyono (2008). Ekskreta yang telah dikoleksi dikeringkan pada sinar matahari, digiling dan dicampur kemudian dilakukan sub-sampling sekitar $40 \mathrm{~g}$, dan disimpan pada temperatur $4^{0} \mathrm{C}$. Semua ayam pada umur 35 hari dipotong untuk mendapatkan digesta ileum, digesta ditimbang, disimpan dalam oven dan dilakukan analisis protein. Protein digesta ileum dikalikan dengan bahan kering ekskreta disebut protein metabolik. Selisih antara protein pakan protein ekskreta dan protein metabolik disebut protein tercerna.

\section{Variabel kecernaan protein}

Dilakukan analisis bahan kering dan protein kasar (AOAC, 2005) dari sampel ekskreta, digesta dan pakan dengan tujuan untuk menentukan kecernaan protein dalam basis bahan kering sehingga protein tercerna dapat dihitung dengan menggunakan rumus :

$$
\text { Ps } \quad=\frac{\mathrm{PKp}-(\mathrm{Pe}-\mathrm{Pm})}{\mathrm{PKp}} \times 100 \%
$$


Keterangan: Protein kasar pakan (PKp), protein ekskreta $(\mathrm{Pe})$, protein metabolik $(\mathrm{Pm})$, kecernaan protein sesungguhnya (Ps).

\section{Hasil dan Pembahasan}

\section{Performa ayam}

Pertumbuhan merupakan perubahan ukuran dalam bentuk perubahan berat badan, komponen tubuh seperti otot, tulang dan organ serta perubahan komponen-komponen kimia dalam karkas (Soeparno, 2005). Pakan yang berkualitas mempunyai peranan penting dalam mempercepat pertumbuhan seekor ternak, untuk mempercepat pertumbuhan tersebut ditambahkan aditif dalam pakan (McDonald, 2002), salah satu aditif pemacu pertumbuhan adalah antibiotik atau sering disebut antibiotic growth promoters (Wahyu, 2004). Tepung cacing tanah dapat dijadikan antibiotik karena mengandung zat aktif lumbricine yang bersifat anti mikroba (Cho et al,. 1998) sehingga penambahan tepung cacing tanah dalam pakan ternak disinyalir dapat meningkatkan performa ternak. Hasil penelitian ternyata menunjukkan penambahan aditif tepung cacing tanah yang sudah diformulasi berpengaruh terhadap performan ayam broiler seperti tersaji pada Tabel 2.

Berdasarkan Tabel 2 pemberian aditif pakan mengandung tepung cacing tanah ternyata berbeda tidak nyata terhadap pertambahan bobot badan ayam, tetapi secara nyata $(\mathrm{P}<0,05)$ menyebabkan perbedaan konsumsi dan konversi ransum (FCR). Rata-rata konsumsi tiap perlakuan selama 32 hari pemeliharaan dalam gram/ekor dapat dilihat pada Gambar 1.

Berdasarkan uji Duncan R0 berbeda nyata $(\mathrm{P}<0,05)$ dengan $\mathrm{R} 1$, $\mathrm{R} 2$, dan $\mathrm{R} 3$, hal ini berarti pakan yang tidak ditambahkan tepung cacing tanah (R0) lebih tinggi konsumsinya dibanding pakan yang ditambahkan tepung cacing tanah (R1, R2, dan R3). Level penambahan aditif tepung cacing tanah berbeda tidak nyata terhadap konsumsi. Hal ini disebabkan karena aditif tepung cacing tanah perananannya serupa dengan penambahan antibiotik dosis rendah dalam pakan. Sesuai dengan hasil penelitian Indrawani (1987) bahwa pemberian anti- biotik dalam pakan dapat menurunkan konsumsi, dan Wiyana (2006) menyatakan bahwa penambahan antibiotik dalam pakan tidak berpengaruh terhadap konsumsi, sedangkan Bintang et al. (1985) menyatakan bahwa penambahan antibiotik dalam pakan dapat meningkatkan konsumsi.

Tepung cacing tanah mempunyai bioaktif anti bakteri yang disebut lumbricine (Cho et al., 1998) yang mampu menghambat perkembangan bakteri patogen dalam dinding usus sehingga populasi bakteri patogen berkurang. Berkurangnya populasi bakteri patogen tersebut akan meningkatkan absorbsi zat makanan. Laju absorbsi makanan berpengaruh terhadap konsumsi sehingga meningkatkan glukosa darah. Glukosa darah yang meningkat (hyperglisemi) akan menurunkan nafsu makan karena akan menstimulasi pusat rasa kenyang pada hypotalamus bagian ventro media hypotalamus (VMH) (Zuprizal, 2006). Peningkatan glukosa darah juga disebabkan oleh kandungan lemak tepung cacing tanah yang tinggi (18,5\%), gliserol dari asam lemak hasil pencernaan diubah menjadi fruktosa dan selanjutnya menjadi glukosa sebagai sumber gula darah (Wahyu, 2004).

Penyebab lain diduga karena absorbsi zat makanan berjalan dengan baik akibat berkurangnya bakteri patogen pada vili-vili usus sehingga ayam tidak banyak mengeluarkan energi untuk mencerna zat makanannya. Adanya antibiotik dalam pakan dapat mengurangi penggunaan energi berlebihan pada saat ternak mengeluarkan antibodi untuk melawan bakteri patogen (Sundu, 2007), sehingga dapat meningkatkan efisiensi pakan. Kekurangan energi akan meningkatkan konsumsi ransum (McDonald, 2002) karena perbedaan konsumsi dipengaruhi oleh kandungan energi dan protein dalam pakan (Zuprizal, 2006). Energi digunakan untuk mempertahankan panas tubuh ayam (Patrick dan Schaible, 1980) dan aktifitas pencernaan (Wahyu, 2004).

Tabel 2 menunjukkan bahwa pertambahan bobot badan berbeda tidak nyata. Hal ini terjadi karena pakan dibuat iso kalori dan iso protein, kalori yang sama membuat pertumbuhan cenderung sama karena energi dimanfaatkan secara maksimal oleh tubuh untuk hidup pokok dan pertumbuhan,

Tabel 2. Pengaruh penambahan tepung cacing tanah (TCT) sebagai aditif pakan terhadap performa ayam (the effect of earthworm meal as feed additive on broiler performances)

\begin{tabular}{lllll}
\hline \hline & \multicolumn{3}{c}{ Perlakuan (treatment) } \\
\cline { 2 - 4 } & \multicolumn{1}{c}{$\mathrm{R} 0$} & $\mathrm{R} 1$ & \multicolumn{1}{c}{$\mathrm{R} 2$} & $\mathrm{R} 3$ \\
\hline Konsumsi pakan (g/ekor) (feed consumption $(\mathrm{g} /$ head)) & $2.309,8^{\mathrm{a}}$ & $2.065^{\mathrm{b}}$ & $2.025,4^{\mathrm{b}}$ & $2.075,3^{\mathrm{b}}$ \\
Pertambahan bobot badan (g/ekor) (gain (g/head)) & $1.097,9$ & $1.157,3$ & $1.126,5$ & $1.157,3$ \\
Konversi pakan (feed conversion) & $2,04^{\mathrm{a}}$ & $1,78^{\mathrm{b}}$ & $1,78^{\mathrm{b}}$ & $1,78^{\mathrm{b}}$ \\
\hline
\end{tabular}

${ }_{\mathrm{a}, \mathrm{b}}$ menunjukkan berbeda nyata $(\mathrm{P}<0,05)$ (shows significantly different $(\mathrm{P}<0.05)$ ).

R0: TCT 0\%, R1: TCT 0,5\%, R2: TCT 1,0\%, R3: TCT 1,5\%. 
sesuai dengan pernyataan McDonald (2002) bahwa asupan energi dalam pakan berguna untuk pertumbuhan disamping untuk kelangsungan hidup ternak tersebut. Broiler membutuhkan energi yang cukup tinggi karena berhubungan dengan kecepatan pertumbuhannya. Broiler disebut juga ayam tipe breast meat type yang berarti pemeliharaan ayam diarahkan untuk pembentukan daging secara cepat (Wibowo, 2005) untuk itu dibutuhkan kandungan energi pakan yang banyak terutama pada saat ayam berumur diatas empat minggu, karena energi dibutuhkan untuk proses pembesaran sel (hypertropy) (Colin et al., 2004). Untuk memacu pertumbuhan disamping energi juga dibutuhkan asupan protein yang sesuai, dengan tingkat pemberian protein dalam pakan yang sama akan memberikan pengaruh pertumbuhan yang sama. Penambahan aditif tepung cacing tanah dalam pakan dapat meningkatkan protein kasar, peningkatan tersebut berkisar antara R1 (0,32\%), R2 (0,63\%), dan R3 (0,95\%) tetapi perbedaan protein pakan tidak menyebabkan perbedaan yang nyata terhadap pertambahan bobot badan. Hal ini terjadi karena perbedaan nilai protein pakan masih dalam kisaran kebutuhan protein pada broiler (19\%-21\%). Colin et al. (2004) menyatakan bahwa batasan protein dalam pakan pada broiler adalah $23 \%$ pada usia starter dan $18,5 \%$ pada usia

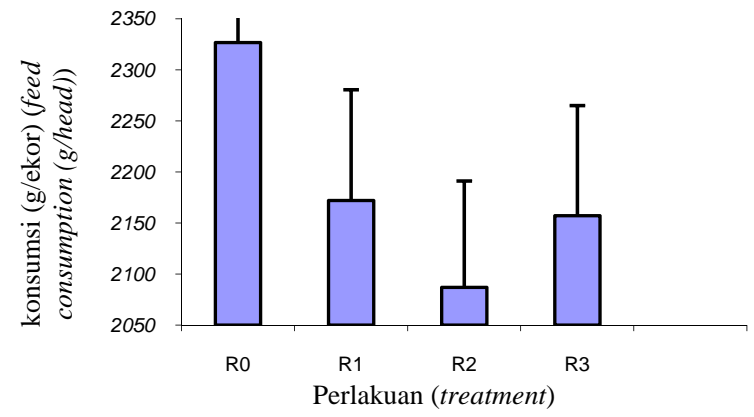

Gambar 1. Grafik pengaruh penambahan tepung cacing tanah (TCT) sebagai aditif terhadap konsumsi (g/ekor) (effect of earthworm meal as feed additive on feed consumption (g/head)). R0: TCT 0\%, R1: TCT 0,5\%, R2: TCT 1,0\%, R3: TCT 1,5\%.

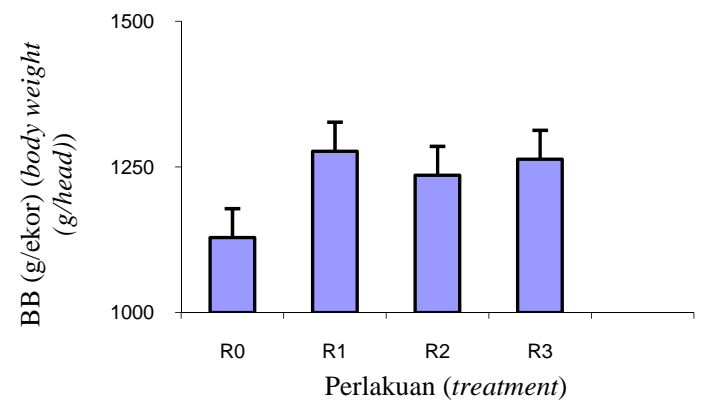

Gambar 2. Grafik pengaruh penambahan tepung cacing tanah (TCT) sebagai aditif terhadap pertambahan bobot badan (g/ekor) (effect of earthworm meal as feed additive on broiler gain (g/head)). R0: TCT 0\%, R1: TCT 0,5\%, R2: TCT 1,0\%, R3: TCT 1,5\%. finisher, sedangkan menurut ketetapan SNI (1995) protein pakan broiler berkisar antara 18-23\%. Resnawati (2004) melaporkan penambahan tepung cacing dalam pakan sampai level 5\% tidak memberikan pengaruh nyata terhadap berat badan broiler. Protein dalam pakan diabsorbsi dalam bentuk asam-asam amino (Zuprizal, 2006) asam amino berperan sebagai penyusun jaringan tubuh dan pertumbuhan (Setiyatwan et al., 2007) terutama pada saat ayam berumur satu sampai tiga minggu karena pada saat usia tersebut terjadi proses pembentukan sel (hyperplasia) secara cepat (Wibowo, 2005). Rata-rata berat badan tiap perlakuan dalam ulangan yang sama dapat dilihat pada Gambar 2.

Pada Gambar 3 dapat dilihat pengaruh penambahan aditif tepung cacing tanah terhadap feed conversion ratio (FCR).

Pengaruh pemberian pakan aditif mengandung tepung cacing tanah terhadap konversi ransum (feed conversion ratio-FCR) berbeda nyata $(\mathrm{P}<0,05)$ dengan kontrol sedangkan antar level penambahan tepung cacing tanah berbeda tidak nyata. Hal ini terjadi karena terdapat perbedaan konsumsi dan perbedaan kecernaan makanan, kecernaan makanan berhubungan dengan absorbsi zat makanan melalui dinding usus (Zuprizal, 2006). Absorbsi zat makanan dipengaruhi tebal dan tipisnya mukosa usus (Wahyu, 2004), semakin banyak zat makanan terabsorbsi semakin baik pertumbuhan ternak tersebut (Cheeke, 2005). Absorbsi zat makanan yang baik dapat mengefisiensikan penggunaan ransum sehingga menurunkan konversi ransum. Penggunaan antibiotik kadar rendah dalam pakan ternyata dapat menipiskan mukosa usus dan meningkatkan efisiensi pakan (Wiyana, 2006).

Hal ini menggambarkan bahwa kandungan lumbricine dalam tepung cacing tanah mampu berperan sebagai antibakteri (Cho et al., 1998). Antibakteri kadar rendah dapat bermanfaat sebagai pemacu pertumbuhan (growth promoters) dalam tubuh ternak (Sundu, 2007). Mekanisme kerja dari antibiotics growth promoters (AGP's) diantaranya adalah bahwa antibiotik dapat membantu memproteksi makanan dari destruksi bakteri, antibiotik

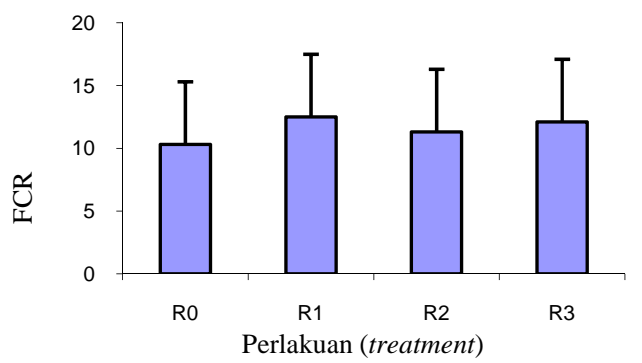

Gambar 3. Grafik pengaruh penambahan tepung cacing tanah (TCT) sebagai aditif terhadap FCR (effect of earthworm meal as feed additive on feed conversion ratio). R0: TCT 0\%, R1: TCT 0,5\%, R2: TCT $1,0 \%$, R3: TCT $1,5 \%$. 
membantu meningkatkan absorpsi nutrisi karena dapat membuat barier di dinding usus, antibiotik dapat menurunkan produksi toksin dari bakteri saluran pencernaan dan menurunkan kejadian infeksi saluran pencernaan subklinik (Feihgner dan Dashkevics, 1987). Antibiotik dapat meningkatkan performa vili usus (Rofiq, 2003), akibatnya efisiensi pakan meningkat karena tingginya absorbsi makanan dalam usus (Wahyu, 2004). Sesuai dengan penelitian Wiyana (2006) dan Indrawani (1987) bahwa pemberian antibiotik dengan level berbeda dapat menurunkan konversi pakan dibandingkan dengan ayam yang tidak diberikan antibiotik.

\section{Profil darah}

Pengaruh penambahan aditif pakan mengandung tepung cacing tanah terhadap profil darah disajikan pada Tabel 3.

Pengaruh penambahan aditif mengandung tepung cacing tanah berbeda nyata dengan kontrol terhadap leukosit dan limfosit kecuali eritrosit. Hal ini terjadi karena asupan protein pada masingmasing pakan perlakuan relatif sama sehingga menyebabkan pembentukan sel eritrosit tidak berbeda, karena diketahui bahwa protein berperan dalam pembentukan eritrosit dan leukosit. Peningkatan jumlah sel eritrosit dapat dilihat pada Gambar 4.

Sistem peredaran darah pada unggas hampir sama dengan hewan mamalia yang membedakan adalah sel darah merah (eritrosit), pada ayam mem- punyai nukleous sedangkan pada mamalia tidak mempunyai nukleous (Yuwanta, 2004). Eritrosit adalah sel yang sangat kecil berisi hemoglobin dan protein pengikat oksigen (Feldman et al., 1995) sehingga jumlah eritrosit dalam darah juga bergantung kepada asupan protein pakan (McDonald, 2002). Dari Tabel 3 terlihat bahwa sebenarnya terjadi kenaikan jumlah sel eritrosit dalam darah, kenaikan tersebut memperlihatkan bahwa tepung cacing tanah mempunyai kontribusi terhadap peningkatan sel darah merah.

Hasil pemeriksaan terhadap diferensial leukosit menunjukkan bahwa penambahan aditif berbeda nyata $(\mathrm{P}<0,05)$ dari kontrol seperti terlihat pada Gambar 5.

Peningkatan jumlah sel leukosit dalam darah disebabkan adanya indikasi perlawanan antibodi tubuh terhadap beberapa kandungan bahan aktif cacing tanah. Tidak ditemukan indikasi infeksi pada ayam dengan kenaikan jumlah sel leukosit karena jumlah leukosit dalam darah ayam masih dalam kisaran normal. Jumlah sel leukosit normal pada ayam antara 12.000-30.000 $\mathrm{\mu l}$ (Feldman et al., 1995). Leukosit yang rendah pada kontrol kemungkinan karena sepsis atau yang disebut leukositopenia (Antinoff, 2005). Leukositopenia adalah penyakit karena perubahan sel leukosit dalam darah yang disebabkan oleh infeksi bakteri atau virus tertentu yang belum diketahui (Antinoff, 2005).

Hasil pemeriksaan terhadap diferensial leukosit khususnya sel limfosit menunjukkan bahwa

Tabel 3. Pengaruh penambahan tepung cacing tanah (TCT) sebagai aditif pakan terhadap profil darah ayam (the effect of earthworm meal as feed additive on broiler blood profiles)

\begin{tabular}{|c|c|c|c|c|}
\hline \multirow{2}{*}{ Profil darah (blood profile) } & \multicolumn{4}{|c|}{ Perlakuan (treatment) } \\
\hline & R0 & $\mathrm{R} 1$ & R2 & R3 \\
\hline Eritrosit $(\mathrm{jt} / \mu \mathrm{l})(\text { erythrocyte }(\text { million } / \mu \mathrm{l}))^{\mathrm{ns}}$ & 10,3 & 12,5 & 11,3 & 12,1 \\
\hline Leukosit $(\mu \mathrm{l})($ leucocyte $(\mu \mathrm{l}))$ & $16.675^{\mathrm{a}}$ & $18.575^{\mathrm{b}}$ & $18.200^{\mathrm{b}}$ & $20.175^{b}$ \\
\hline Limfosit (\%) (lymphocyte (\%)) & $15,2^{\mathrm{a}}$ & $22,7^{\mathrm{b}}$ & $21,8^{\mathrm{b}}$ & $23,6^{\mathrm{b}}$ \\
\hline
\end{tabular}

a,b menunjukkan berbeda nyata $(\mathrm{P}<0,05)$ (shows significantly different $(\mathrm{P}<0.05)$ ).

R0: TCT 0\%, R1: TCT 0,5\%, R2: TCT 1,0\%, R3: TCT 1,5\%.

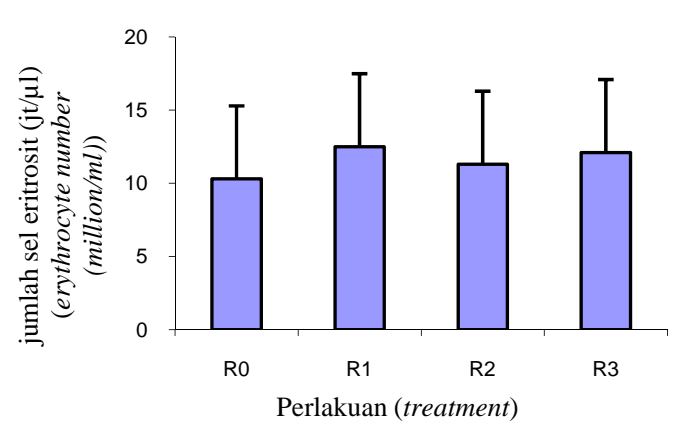

Gambar 4. Grafik pengaruh penambahan tepung cacing tanah (TCT) sebagai aditif terhadap jumlah sel eritrosit (jt/ $\mu \mathrm{l})$ (effect of earthworm meal as feed additive on the number of erythrocyte cell (million/ $\mu l$ )). R0: TCT 0\%, R1: TCT 0,5\%, R2: TCT 1,0\%, R3: TCT $1,5 \%$.

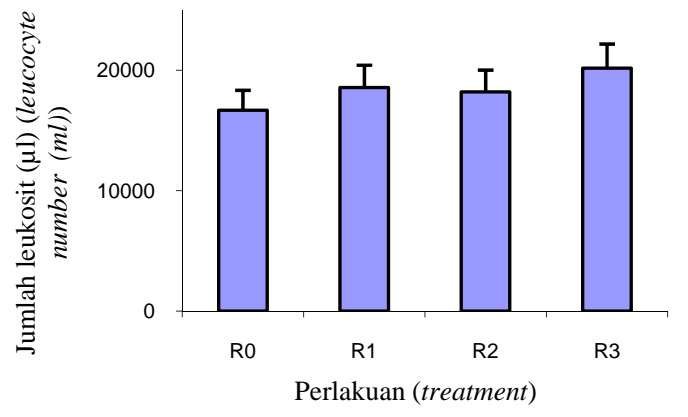

Gambar 5. Grafik pengaruh penambahan tepung cacing tanah (TCT) sebagai aditif terhadap jumlah sel leukosit $(\mu \mathrm{l})$ (effect of earthworm meal as feed additive on the number of leucocyte cell $(\mu \mathrm{l}))$. R0: TCT 0\%, R1: TCT 0,5\%, R2: TCT 1,0\%, R3: TCT $1,5 \%$. 


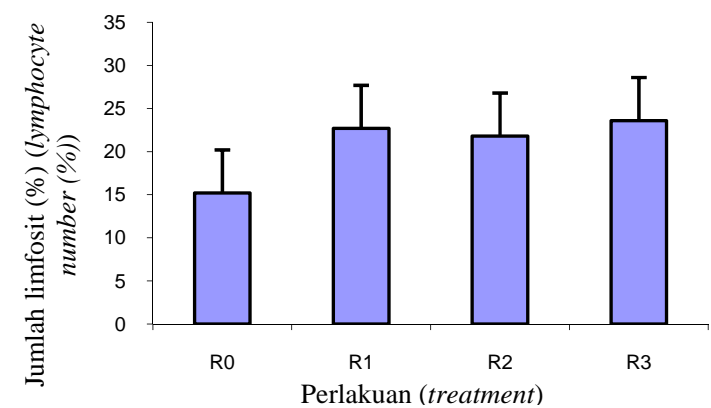

Gambar 6. Grafik pengaruh penambahan tepung cacing tanah (TCT) sebagai aditif terhadap jumlah sel limfosit (\%) (effect of earthworm meal as feed additive on the number of lymphocyte cell (\%)).R0: TCT 0\%, R1: TCT 0,5\%, R2: TCT 1,0\%, R3: TCT $1,5 \%$.

ayam dalam kondisi normal walaupun ditemukan pada kontrol terjadi penurunan limfosit sampai ambang batas jumlah sel limfosit yang diperbolehkan. Menurut Feldman et al. (1995) jumlah limfosit normal pada ayam adalah $15-40 \%$ dari total leukosit. Grafik perubahan jumlah sel leukosit dapat dilihat pada Gambar 6.

Perubahan jumlah limfosit mengikuti jumlah leukosit dalam darah dan diketahui bahwa limfosit berperan dalam pembentukan antibodi (Apanius et al., 2000). Peningkatan jumlah sel limfosit menyebabkan penyakit limfositosis, tetapi limfositosis merupakan keadaan yang aneh pada unggas, keadaan limfositosis absolut mengakibatkan terjadinya limfositik leukemia (Antinoff, 2005).

Hasil penelitian diketahui bahwa jumlah sel limfosit pada level penambahan tepung cacing tanah cenderung sama kecuali pada kontrol yang mengalami penurunan. Hasil ini memberikan indikasi bahwa aditif cacing tanah dapat meningkatkan imunitas pada ayam broiler sesuai dengan laporan Damayanti et al. (2009) bahwa penambahan cacing tanah sebesar 75\% (b/v) dalam $100 \mu$ l DMSO dapat menghambat perkembangan bakteri Salmonela pullorum sehingga merupakan indikator peningkatan imunity pada ayam. Liu et al. (2004) mengatakan bahwa cacing tanah Lumbricus rubellus dapat menstimulasi kekebalan. Secara alamiah cacing tanah mempunyai bahan aktif antimikroba berupa peptida atau protein yang berperan sebagai pertahanan utama terhadap mikroba tanah. Annelida mengembangkan sistem kekebalan seluler terhadap patogen meliputi fagositosis, enkapsulasi, dan sitotoksitas (Salzet et al., 2006). Rahimi dan Kahksetidi (2006) mengatakan bahwa tidak ada pengaruh antibiotik terhadap jumlah sel leukosit dan limfosit dalam darah kecuali ayam dalam keadaan infeksi.

\section{Kecernaan protein}

Tepung cacing tanah (Lumbricus rubellus) dapat dimanfaatkan sebagai sumber pakan (Resnawati, 2002), mengandung protein kasar 63\% bahan kering (Damayanti et al., 2008) dengan indeks asam amino 58,67\% (Istiqomah et al., 2009) dan memiliki efisiensi dan retensi nitrogen yang baik ketika diberi pakan sampai taraf 72-215 g/kg (Edwards, 1985). Kandungan protein tepung cacing tanah tersebut diharapkan dapat memperbaiki kualitas pakan dan kecernaan protein pada ayam. Hasil pengukuran kecernaan protein sejati (true protein digestibility) pada penambahan aditif mengandung tepung cacing tanah terhadap ayam broiler berturutturut adalah R0 (81,75\%), R1 (90,48\%), R2 (85,99\%), dan R3 (91,69\%).

Hasil statistik menunjukkan bahwa kecernaan protein sejati (true protein digestibility) pada ayam perlakuan ternyata berbeda nyata $(\mathrm{P}<0,05)$ dengan kontrol (R0), R1 dengan R3 berbeda tidak nyata dan R0 berbeda tidak nyata dengan R2, sedangkan R2 berbeda nyata $(\mathrm{P}<0,01)$ dengan $\mathrm{R} 3$. Hal ini menggambarkan bahwa kualitas pakan dengan penambahan aditif tepung cacing tanah lebih baik dari pakan tanpa penambahan tepung cacing tanah. Mulyono (2008) mengatakan jika kualitas pakan menurun akan terjadi penurunan kecernaan. Disamping kualitas pakan, kecernaan juga dipengaruhi oleh absorbsi zat makanan dalam mukosa usus (Cheeke, 2005) dan ketebalan lapisan usus pada ayam (Wahyu, 2004). Kualitas protein pakan berpengaruh terhadap kecernaan protein pada ternak ayam, protein mengalami perombakan yang dilakukan oleh enzim-enzim hidrolitik (Wahyu, 2004). Protein pertama kali dicerna pada proventrikulus dimana adanya glandular stomach yang mensekresikan pepsinogen dan $\mathrm{HCl}$ untuk memecah struktur tersier protein pakan (Yuwanta, 2004). Segera setelah proteolisis dimulai oleh pepsin di usus halus, selanjutnya di rombak oleh bantuan enzim tripsin, kemotripsin dan elastase (Wahyu, 2004). Penyempurnaan pencernaan protein dilakukan oleh erepsin (enzim proteolitik) dan menghasilkan asam-asam amino, selanjutnya di absorbsi (Zuprizal, 2006). Absorbsi zat makanan juga dipengaruhi oleh mikroba patogen di dalam usus karena bakteri patogen dapat menimbulkan penebalan dinding usus (Wahyu, 2004). Peningkatan nilai kecernaan protein pakan dengan penambahan tepung cacing tanah diduga karena terjadi penipisan mukosa usus sehingga menyebabkan absorbsi zat makanan meningkat. Penambahan aditif antibiotik dapat memperbaiki dinding usus (Wiyana, 2006) sehingga dapat meningkatkan kecernaan. Penggunaan antibiotik kadar rendah dalam 
pakan dapat meningkatkan kapasitas absorbsi asam amino (Zuprizal, 2006). Nilai kecernaan pakan yang rendah menyebabkan konversi pakan cenderung meningkat (Martawidjaya et al., 1999).

\section{Kesimpulan}

Penggunaan tepung cacing tanah sebagai aditif sampai level $1,5 \%$ pada pakan ayam broiler dapat memperbaiki performa ayam, mampu memperbaiki kesehatan ternak dilihat dari profil darah dan meningkatkan kecernaan protein. Berdasarkan kandungan lumbricine yang diduga sebagai antibakteri maka tepung cacing tanah (TCT) berpotensi digunakan sebagai bahan aditif pemacu pertumbuhan (growth promoters) dalam pakan sampai level 1,5\% total ransum.

\section{Daftar Pustaka}

Antinoff, N. 2005. From the Annnual Meeting: Avian Laboratory Diagnostics. Gulf Coast Veterinary Specialists. Gulf Coast Avian and Exotics. Houston, TX.

AOAC. 2005. Official Method of Analysis. In: Helrich, K. (ed.). $15^{\text {th }}$ ed, Association of Official Analytical Chemists (AOAC). Arlington, V.A.

Apanius, V., N. Yorinks., E. Bermingbam., R.E. Ricklefs. 2000. Island and Taxon Effects in Parasitism and Resistance of Lesser Antilean Birds. Available at http://www.bioone. org pelselrvSESSID=42. Accession date: October 20, 2009.

Bintang, K., G.N. Made, dan N. Supardjata. 1985. Pengaruh antibiotika kadarluarsa tetrasiklin dan ampisilin terhadap pertumbuhan broiler. Prosiding Seminar Peternakan Unggas dan Aneka Ternak. Ciawi. Bogor.

Bogaard, Van De. and E.E. Stobberingh. 1999. Antibiotic usage in animals: impact on bacterial resistance and public health. Drugs. 58(4):589-607.

Castanon, J.I.R. 2007. History of the use of antibiotic as growth promotors in european poultry feeds. Poultry Science, J. 86:24662471.

Cheeke, P.R. 2005. Applied Animal Nutrition, Feeds and Feeding. $3^{\text {rd }}$ ed, Pearson Prentice Hall, New Jersey.

Cho, J.H., C.B. Park, Y.G. Yoon, and S.C. Kim. 1998. Lumbricin I, a novel proline-rich antimicrobial peptide from the earthworm: purification, cDNA cloning and molecular characterization. Biochim. Biophys. Acta. 1408(1):67-76.
Colin, G.S., G. Brant, and M.E. Ensminger. 2004. Poultry Science. $4^{\text {th }}$ ed. Pearson education, Inc, New Jersey.

Cook, D., D. Brata., Z. Szep., J. Dougan, and D. Nepert. 1997. Effects of Antibiotics on Animal Feed. Available at http://www.udel. edu/chem/C465/senior/fall97/feed/present.hm l. Accession date: April 25, 2008.

Damayanti, E., H. Julendra, and A. Sofyan. 2008. Aktivitas antibakteri tepung cacing tanah (Lumbricus rubellus) dengan metode pembuatan yang berbeda terhadap Escherichia coli. Prosiding Seminar Nasional Pangan. Yogyakarta, 17 Januari 2008. Pp. MK 54-60.

Damayanti, E., A. Sofyan, H. Julendra, dan T. Untari. 2009. Pemanfaatan tepung cacing tanah (Lumbricus rubellus) sebagai agensia anti-pullorum dalam imbuhan pakan ayam broiler. Jurnal Ilmu Ternak dan Veteriner 14(2):83-89.

Donoghue, dan J. 2003. Antibiotics residues in poultry tissues and eggs: human health concerns?. Poultry Science, J. 82:618-621.

Edwards, C.A. 1985. Production of Feed Protein from Animal Waste by Earthworms. Phil. Trans. R. Soc. Lond. B 310:299-307.

Feighner, S.D., and M.P. Dashkevicz. 1987. Subtherapeutic levels of antibiotics in poultry feeds and their effects on weight gain, feed efficiency, and bacterial cholyltaurine hydrolase activity. Appl. Environ. Microbiol. 53:331-336.

Feldman, B.F., J.G. Zinkl., and N.C. Jain. 1995. Schalm's Veterinary Hematology. $5^{\text {th }}$ ed. Lippincot Williams and Wilkins. pp:11471153.

Hakim, R.S. 2005. Prospek probiotik pada broiler. CP- Bulletin Service ed, Desember No 72/VI.

Istiqomah, L., A. Sofyan., E. Damayanti, and H. Julendra. 2009. Amino acid profile of earthworm and earthworm meal (Lumbricus rubellus) for animal seedstuff. J. Indo. Tropical anim. Agri. 34(4):253-257.

Indrawani, Y.M. 1987. Kajian terhadap beberapa antibiotika sebagai aditif dalam ransum ayam broiler. Tesis. Program Studi Ilmu Peternakan. Jurusan Ilmu-ilmu Pertanian. Fakultas Pasca Sarjana. Universitas Gadjah Mada.

Julendra, H. dan A. Sofyan. 2007. Uji in vitro penghambatan aktivitas Escherichia coli dengan tepung cacing tanah (Lumbricus rubellus). Media Peternakan, Jurnal Ilmu Pengetahuan dan Teknologi Peternakan 30(1):1-70.

Khachatryan, A.R., T.E. Besser, D.D. Hancock, and D.R. Call. 2006. Use of a nonmedicated 
dietary supplement correlates with increased prevalence of streptomycin-sulfa-tetracycline-resistant Escherichia coli on a dairy farm. Applied and Environmental Microbiology 72(7):4583-4588.

Lange, S., E. Kauschke, W. Mohrig, and E.L. Cooper. 1999. Biochemical characteristics of eiseniapore, a pore-forming protein in the coelomic fluid of earthworms. Eur. J. Biochem. 262:547-556.

Lee, K.W., H. Evert., H.J. Kappert., H. Wouterse., M. Frehner, and A.C. Beynen. 2004. Cinnamaldehyde but not thymol counteracts the carboxymetyl cellulose-induced growth depretion in female broiler chickens. Int. J. of Poultry Sci. 9:608-612.

Liu, Y-Q., Z-J Sun., C. Wang., S-J. Li., and Y-Z. Liu. 2004. Purification of a novel antibacterial short peptide in earthworm Eisenia foetida. Acta Biochimica et Biophysica Sinica 36(4):297-302.

Martawidjaja, M., B. Setiadi, dan S.S. Sitorus. 1999. Pengaruh tingkat protein energi ransum terhadap kinerja produksi kambing kacang muda. Balai Penelitian Ternak. Jurnal Ilmu Ternak dan Veteriner 4(3):161-171.

McDonald, P. 2002. Animal Nutrition. $6^{\text {th }}$ ed. Prentice Hall. London.

Mulyono, A.M.W. 2008. Mutan jamur selulolitik Trichoderma sp untuk meningkatkan kualitas onggok sebagai bahan pakan ayam broiler. Disertasi. Program Studi Ilmu Peternakan. Sekolah Pasca Sarjana. Universitas Gadjah Mada.

Patrick, H. and P.J. Schaible. 1980. Poultry Feed and Nutrition. Aci Publ., Co., Inc. Westport. Connecticut.

Rahimi, S.H. and A. Kahksefidi. 2006. A comparisn between the effect of a probiotic (Bioplus 2B) and antibiotic virginiamycin on the performance of broiler chicken under heat stress condition. Iranian J. of Veterinary Research 7(3):23-28.

Resnawati, H. 2004. Bobot potongan karkas dan lemak abdomen ayam ras pedaging yang diberi ransum mengandung tepung cacing tanah. Prosiding Seminar Nasional Teknologi Peternakan dan Veteriner. Bogor, 4-5 Agustus 2004. Pp. 473-478.

Rofiq, M.N. 2003. Pengaruh pakan berbahan baku lokal terhadap performans vili usus halus ayam broiler. Jurnal Sains dan Teknologi Indonesia 5(5):190-194.

Salzet, M., A. Tasiemski, and E. Cooper. 2006. Innate Immunity in Lophotrochozoans: The Annelids. Curr. Pharm. Des. 12:1-8.

Setiyatwan, H., W.G. Piliang., D.T.H. Sihombing., W. Manalu, and A. Anang. 2007. Suplementasi fitase, seng, dan tembaga dalam ransum sebagai stimulan pertumbuhan ayam broiler. Media Peternakan, Jurnal Ilmu Pengetahuan dan Teknologi Peternakan 30(2):139-145.

Soeparno. 2005. Ilmu dan Teknologi Daging. Cetakan ke IV. Gadjah Mada University Press. Yogyakarta.

Sofyan, A., E. Damayanti, dan H. Julendra. 2008. Aktivitas antibakteri dan retensi nitrogen tepung cacing tanah sebagai pakan imbuhan dengan taraf penambahan kitosan. Jurnal Ilmu Ternak dan Veteriner 13(3):182-188.

Steel, R.G.D., and J.H. Torrie. 1993. Prinsip dan Prosedur Statistika, Suatu Pendekatan Biometrik, Penerjemah Sumantri, Penerbit PT. Gramedia Putaka Sarana, Jakarta.

Sundu, B. 2007. Neraca rugi laba penggunaan antibiotics growth promotor's (AGP). Majalah Poultry Indonesia Vol. II:44-45.

Tasiemski, A., D. Schikorski, F.L. Marrec-Croq, C.P-V. Camp, C. Boidin-Wichlacz, and P.E. Sautiere. 2006. Hestidin: a novel antimicrobial peptide containing bromotryptophan constitutively expressed in the NK cells-like of the marine annelid, Nereis diversicolor. Developmental and Comparative Immunology, I (IIII) III-III.

Wahyu, J. 2004. Ilmu Nutrisi Unggas. Cetakan ke5, Gadjah Mada University Press, Yogyakarta.

Wibowo, H. 2005. Keterlambatan Pertumbuhan dan Produktivitas pada Ayam Ras. PT. Sumber Multivita, Jakarta, Indonesia.

Wiyana, I.K.A. 2006. Pengaruh oxsitetrasiklin dan amoksisilin sebagai aditif pakan terhadap performa, residu dalam jaringan dan eskreta broiler. Tesis. Fakultas Peternakan. Universitas Gadjah Mada. Yogyakarta.

Yuwanta, T. 2004. Dasar ternak Unggas. Penerbit Kanisius, Yogyakarta.

Zuprizal. 2006. Nutrisi Unggas. Fakultas Peternakan. Universitas Gadjah Mada. Yogyakarta. 